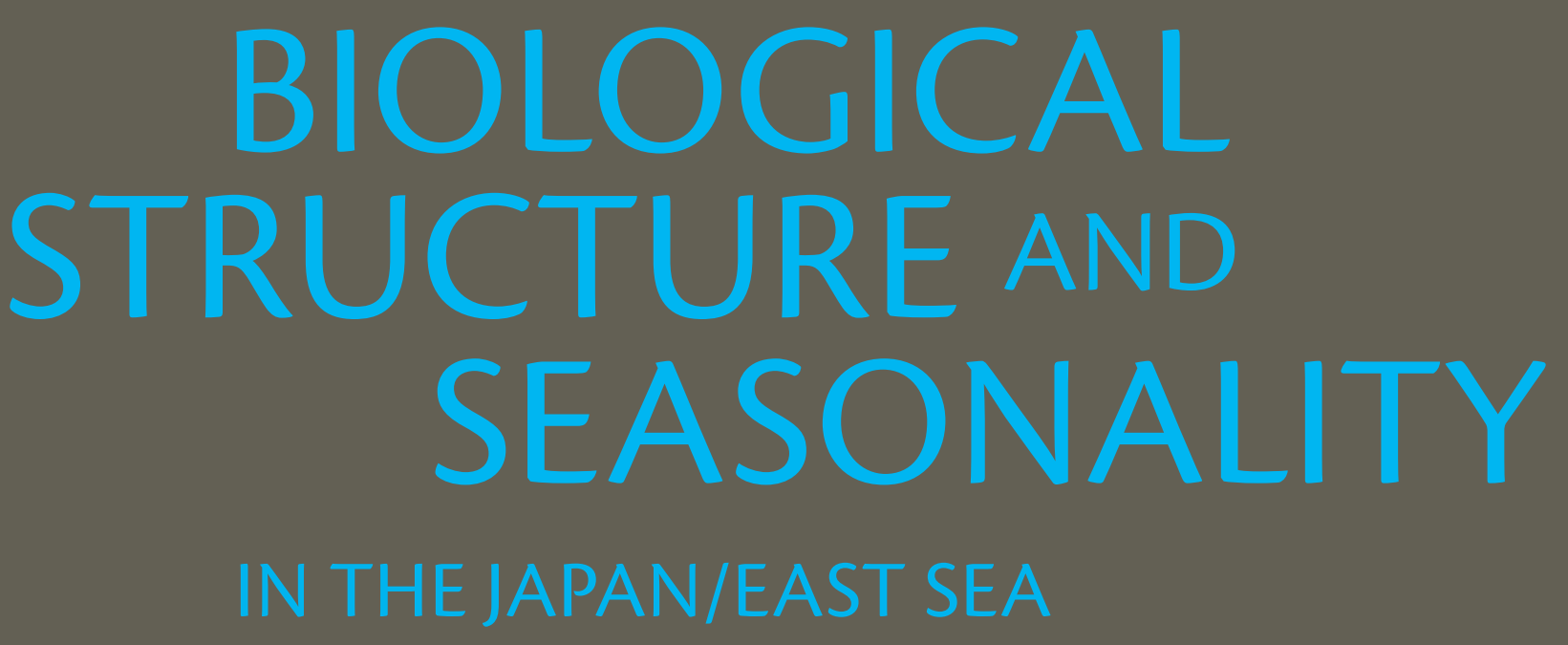

BY CARIN ASHJIAN, ROBERT ARNONE, CABELL DAVIS, BURTON JONES, MATI KAHRU, CRAIG LEE, AND B. GREGORY MITCHELL

The Japan/East Sea (JES) contains several oceanic regions separated by dynamic boundaries. These distinct regions, and the physical features that establish and maintain the boundaries between the regions, have significant impacts on its ocean biology. Until recently, most studies of the biology of the JES have focused on nearshore regions, with few detailed studies of the interior of the JES or the dynamic features that define the different regions. In addition, the classic sampling methods used in previous work have not allowed high-resolution studies of biological-physical interactions associated with key dynamic mesoscale frontal zones, quasi-synoptic surveys of water column and biological structure in three dimensions, or broad-scale description of the seasonal cycles in the different biogeographic regions of the JES.

\title{
A UNIQUE BASIN
}

The central basin of the JES contains two primary biogeographic regions, defined by the dominant currents and hydrographic structures (Figures 1 and 2). The region is bisected by the dramatic the Subpolar Front (SPF) and its associated mesoscale circulation. The SPF persists between the cold water in the north and the warmer subtropical water in the south and flows from west to east from the Korean Peninsula to Tsugaru Strait (e.g., Isoda et al., 1991; Isoda, 1994; Preller and Hogan, 1998; Talley et al., 2004; Lee and Niiler, 2005). The Tsushima Current brings warm, 


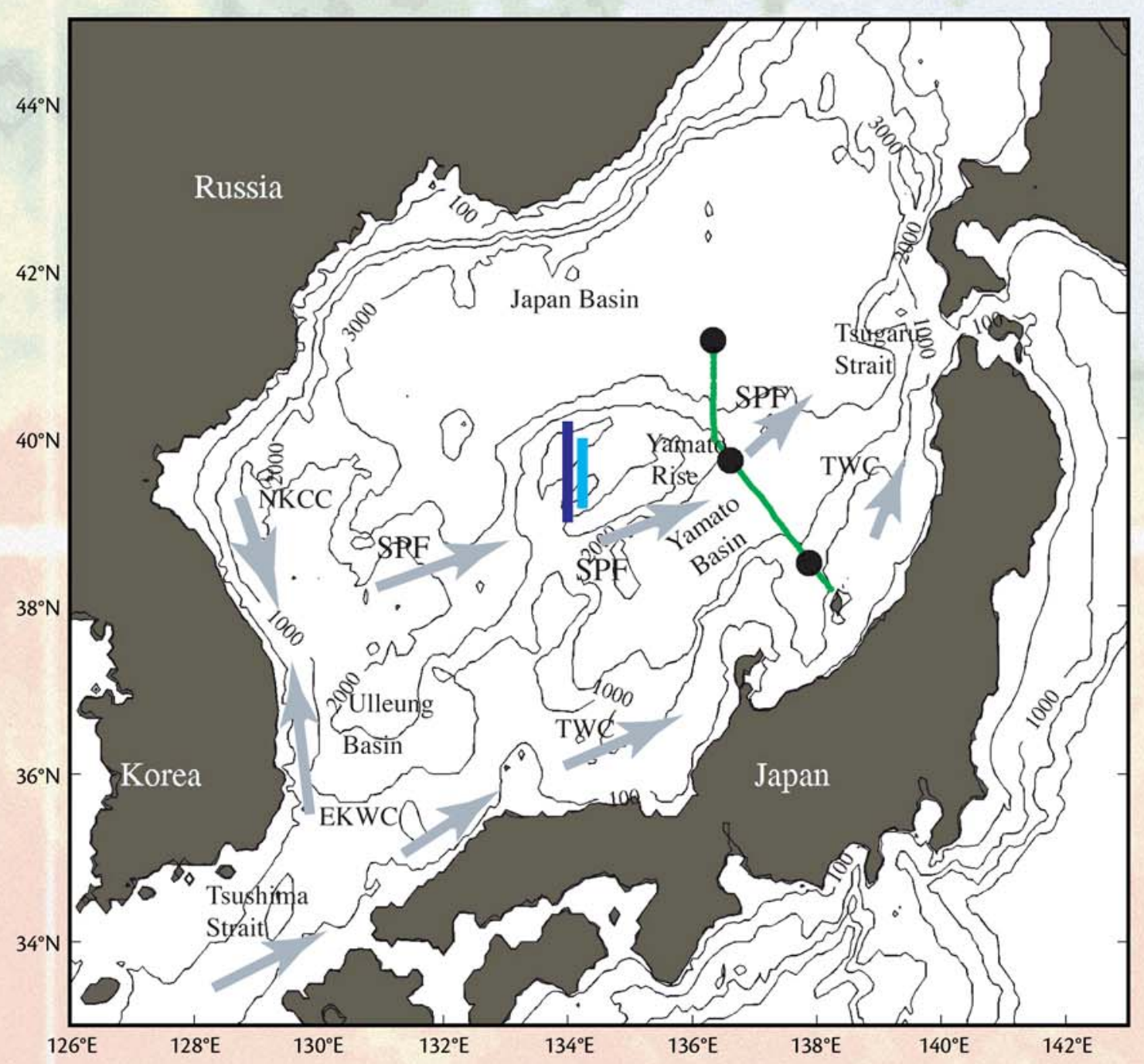

Figure 1. Geographic features and currents of the Japan/East Sea with locations of the Video Plankton Recorder (VPR) (July 4-7, 1999, green line) and SeaSoar (May 22, 1999, blue line; January 27, 2000 cyan line) data and of the net tows (black-filled circles) conducted during the July VPR cruise shown (EKWC=East Korean Warm Current, NKCC=North Korean Cold Current, SPF=Subpolar Front, TWC=Tsushima Warm Current). 

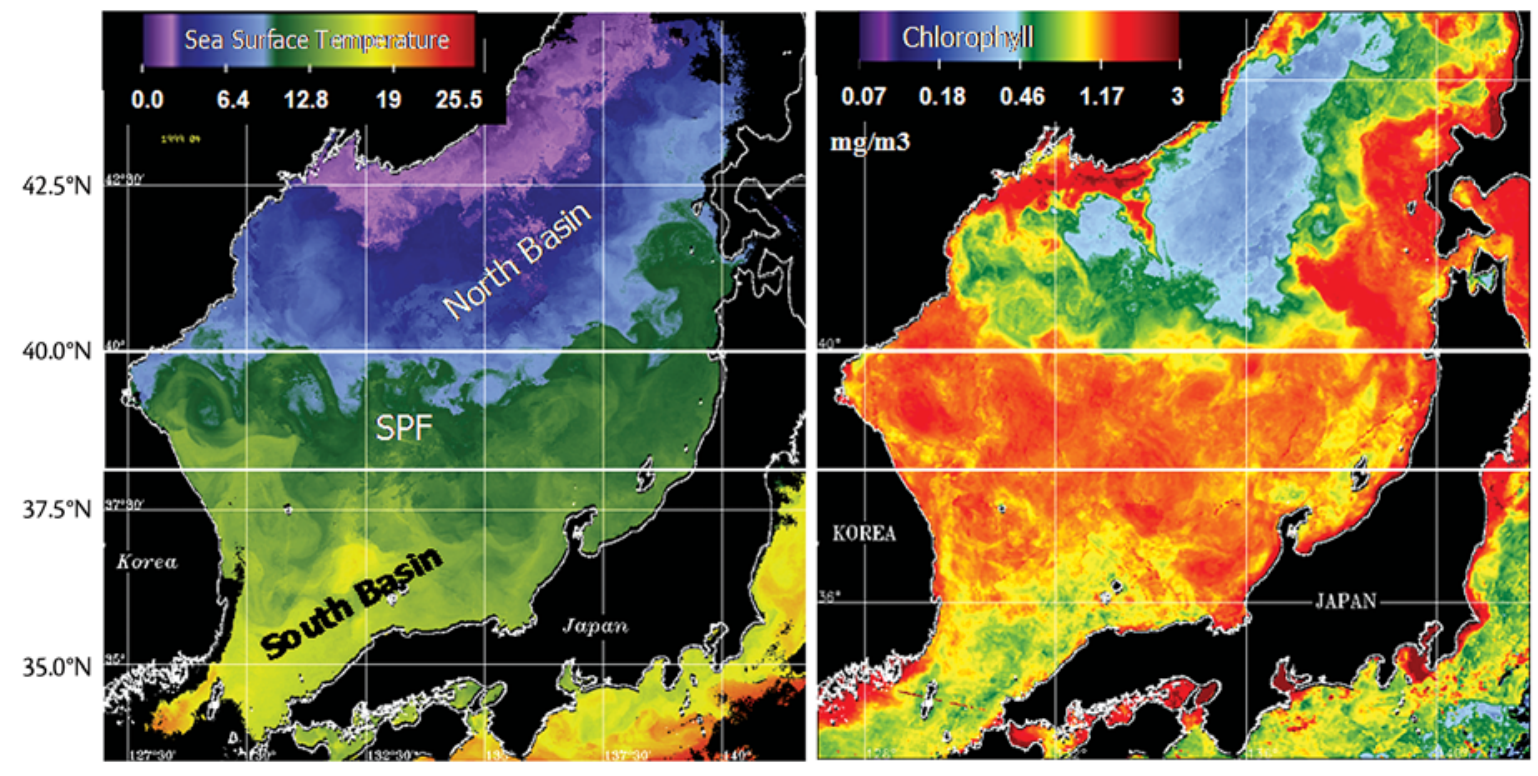

Figure 2. April 1999 monthly averages of temperature $\left(\mathrm{T}^{\circ} \mathrm{C}\right)$ (left panel) and chlorophyll ( $\mathrm{mg} \mathrm{m}^{-3}$ ) (right panel) from satellites, showing the distinct northern and southern regions of the JES separated by the Subpolar Front (SPF) (delineated by the horizontal white lines). Sea surface temperature and chlorophyll from NOAA Advanced Very High Resolution Radiometer (AVHRR) and Sea-viewing Wide Field-of-view Sensor (SeaWIFS) satellites, respectively.

tropical water into the JES through Tsushima Strait to the south and flows north along the western coast of Japan (e.g., Preller and Hogan, 1998; Hase et al., 1999; Talley et al., 2004). A branch of the Tsushima Current flows north along east coast of the Korean Peninsula as the East Korean Warm Current (EKWC) (e.g., Tomczak and Godfrey, 1994; Hase et al., 1999). The North Korean Cold Current
(NKCC) flows south along the Russian coast and the northern Korean Peninsula, intersecting the EKWC at the inception of the SPF (e.g., Huh and Shim, 1987). In winter, deep low-pressure systems draw cold dry Siberian air masses over the northern JES, forming cold dense waters that result in deep convective mixing (e.g., Talley et al., 2003, this issue; Dorman et al., 2004; Khelif et al.,
Carin Ashjian (cashjian@whoi.edu) is Associate Scientist, Department of Biology, Woods Hole Oceanographic Institution, Woods Hole, MA, USA. Robert Arnone is Head, Ocean Sciences Branch, Naval Research Laboratory, Stennis Space Center, MS, USA. Cabell Davis is Senior Scientist, Department of Biology, Woods Hole Oceanographic Institution, Woods Hole, MA, USA. Burton Jones is Research Associate Professor, Marine Environmental Biology, University of Southern California, Los Angeles, CA, USA. Mati Kahru is Associate Specialist, Scripps Institution of Oceanography, University of California, San Diego, La Jolla, CA, USA. Craig Lee is Senior Oceanographer, Applied Physics Laboratory, University of Washington, Seattle, WA, USA. B. Gregory Mitchell is Research Biologist, Scripps Institution of Oceanography, University of California, San Diego, La Jolla, CA, USA.
2005; Lee et al., this issue). To the north of the SPF, the JES follows a distinct temperate-sub-polar seasonal cycle for water temperature and associated biological characteristics (e.g., primary production, copepod species, phytoplankton type) (Figure 3). By contrast, the region to the south of the SPF is much warmer, has considerably less seasonality and is characterized by more tropical biological characteristics and species (Meshcheryakova, 1960; Nishimura, 1969; Morioka et al., 1977; Miller and Terazaki, 1989; Park et al., 1991; Hirakawa et al., 1995).

Because of its relatively small size, this semi-enclosed basin provides access over short distances to features typical of much larger ocean basins and thus is an ideal model system for intensive process studies to understand ocean dy- 

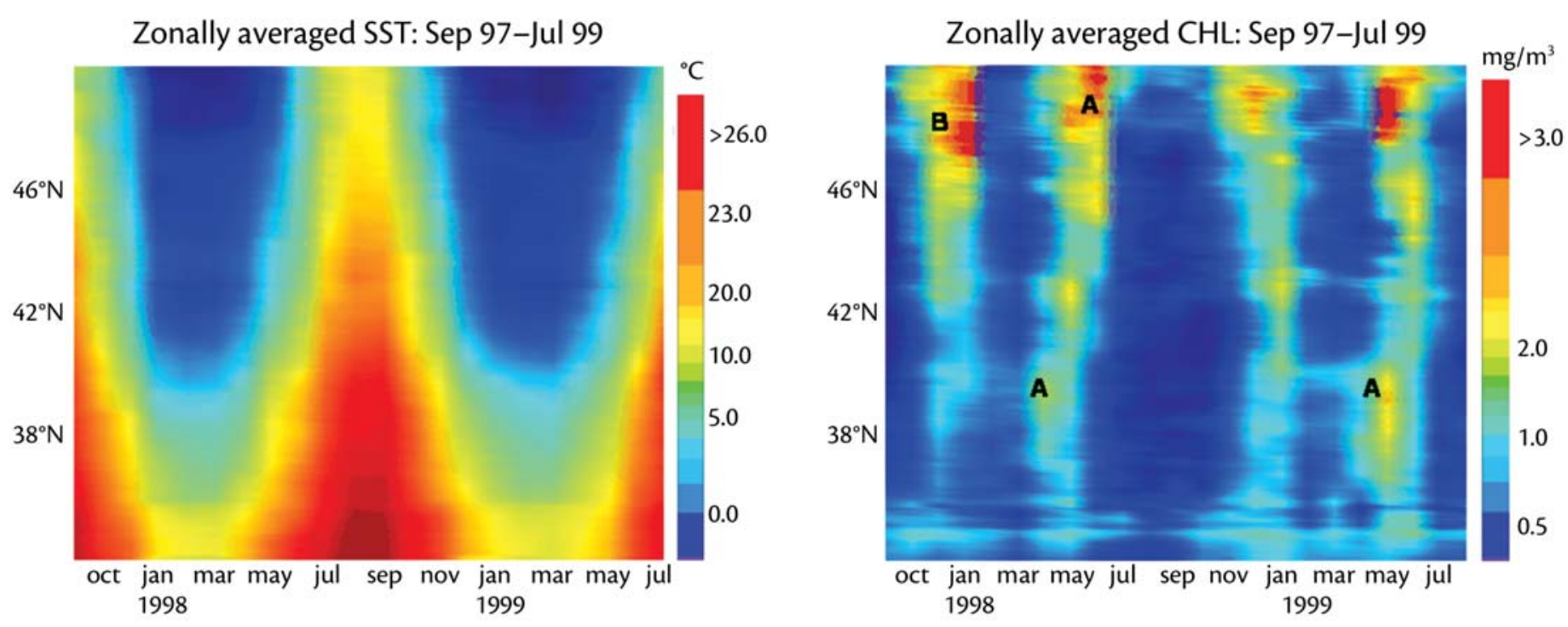

Figure 3. Seasonal progression of satellite-derived sea surface temperature (left) and chlorophyll (right) from October 1997 to July 1999 , from weekly composites, extending from the southern to northern regions and including the 1999 summer field season of the JES program. The spring bloom (A) and the fall bloom (B) are shown for 1998 and 1999.

namics that may be relevant to larger basins (e.g., Riser and Jacobs, 2005). Dynamic features, such as the SPF, may be surveyed rapidly and relatively synoptically, yielding high-resolution coincident descriptions of hydrography and biology with which to identify and understand biological-physical associations and interactions.

The Office of Naval Research (ONR) JES Program provided an opportunity to describe these biological-physical linkages using a suite of high-resolution methods. During 1999-2000, three cruises were conducted to acquire coincident high-spatial-resolution biological and physical measurements using two different towed sampling platforms equipped with optical and physical sensors (V-Fin and SeaSoar). The larger time- and space-scale distribution of phytoplank- ton and temperature were obtained using satellite observations, providing context for interpreting the high-resolution studies and permitting a rigorous analysis of seasonality in phytoplankton and primary production over the entire JES. These observations highlighted how critically important the dominant physical features, such as the SPF, are to defining biological distributions over regional to fine scales. Here we describe selected findings from the JES biological sampling program, specifically targeted at identifying the role of dynamic physical boundaries such as the SPF in structuring the ecosystem.

The present compilation of projects has two overall objectives: (1) describe spatial and temporal variability at the basin and annual to decadal scales using analysis of satellite imagery and
(2) examine more closely the role of the SPF as a boundary between the northern and southern biogeographic regions by considering the biological-physical associations in this dynamic feature using high-resolution hydrographic and biological data from the upper water column.

\section{BIO-OPTICAL TIME SERIES}

Time series of sea surface temperature (SST) and ocean color (chlorophyll) from satellite imagery demonstrated the biogeography of the JES, basin-wide spatial and temporal variability in both physical and biological characteristics, the persistence and role of the SPF, and annual cycles in biology and physics (Gould and Arnone, 2004). For example, strong spatial gradients in SST and chlorophyll across the basin were observed in 
April 1999 (Figure 2). The SPF separated the warmer southern basin from the cold northern waters, with an $\sim 7^{\circ} \mathrm{C}$ temperature gradient between the two regions. Considerable mesoscale variability in the path and structure of the SPF (eddies, filaments) also is evident.

Complex patterns in biology in April 1999 also were associated with SST or physical structures. High chlorophyll $\left(\sim 2 \mathrm{mg} \mathrm{m}^{-3}\right)$ on the western boundary was associated with coastal upwelling in the EKWC; this elevated chlorophyll propagated northward in the EKWC and then eastward where the flow separates from the coast at $\sim 40^{\circ} \mathrm{N}$ in a series of undulating rings and eddies as part of the SPF. A quasi-permanent eddy located south of where the EKWC and the East Korea Warm Current (EKCC) merge near $40^{\circ} \mathrm{N}$ (Kim et al., 1991, 1996; Shin where upwelling does not occur (note also very high nearshore chlorophyll associated with the coast). Regions of elevated chlorophyll also were observed in the northern basin off the coast of Russia as well as to the north of Tsugaru Strait as part of the northward extension of the SPF. Gradients in the characteristic circulation features were clearly defined in the SST and the surface chlorophyll, although these two variables did not always covary.

Annual cycles of chlorophyll and SST across the JES for 1998-1999 were created from weekly composites of daily satellite images (Arnone and Parsons, 2004) (Figure 3). The SST cycle corresponded with the annual solar photosynthetically available radiation cycle (not shown), with considerable spatial and temporal variation across the basin. Sea-surface

\section{Until recently, most studies of the biology}

$$
\text { of the JES have focused on nearshore regions, }
$$
with few detailed studies of the interior of

\section{the JES or the dynamic features that} define the different regions.

et al., 1995; Suh et al., 1999; Ashjian et al., 2005; Mitchell et al., 2005) also may be associated with elevated chlorophyll. By contrast, much lower chlorophyll $\left(<0.3 \mathrm{mg} \mathrm{m}^{-3}\right)$ was observed in the eastern portion of the southern basin off the Japan coast, where the oligotrophic Tsushima Current moves northward and warming began in the south in March but later (May-June) in northern regions. Maximum temperatures occurred in all regions in September.

Phytoplankton blooms developed in both spring and fall of both years (Figure 3). The spring phytoplankton bloom began in the southern basin in March and propagated northward, reaching peak chlorophyll $\left(\sim 5 \mathrm{mg} \mathrm{m}^{-3}\right)$ at $\sim 47^{\circ} \mathrm{N}$ in late May. The spring bloom was followed by a rapid decay during the summer. A particularly strong (> $1 \mathrm{mg} \mathrm{chl} \mathrm{m}^{-3}$ ) phytoplankton bloom occurred at the SPF $\left(\sim 42^{\circ} \mathrm{N}\right)$, perhaps associated with the complex mesoscale structure of the front (anticyclonic eddies, filaments) (Figure 2). The autumn phytoplankton bloom began in November and persisted until January. This autumn bloom was observed each year, but the strength and timing varied spatially and temporally. The bloom was quite strong ( $>1 \mathrm{mg} \mathrm{chl} \mathrm{m}^{-3}$ ) in the northern basin, but considerably lower in the southern basin.

\section{VARIATIONS IN PRIMARY} PRODUCTION

Spatial and temporal variations in primary production were further explored by considering satellite-derived chlorophyll in different regions over a tenyear period (1996-2006). The analysis was based on a 10-year time series of satellite-derived chlorophyll from the Ocean Color and Temperature Sensor (OCTS) and Sea-viewing Wide Fieldof-view Sensor (SeaWiFS) satellites for which monthly means were calculated. Monthly anomalies from the mean then were constructed by calculating the ratio of the monthly mean chlorophyll for each month in the time series relative to the long-term mean for that month. The major regions in the basin then were identified using principal components and empirical orthogonal functions based on the 10-year series of chlorophyll anomalies. The first principal component objectively separated the north- 

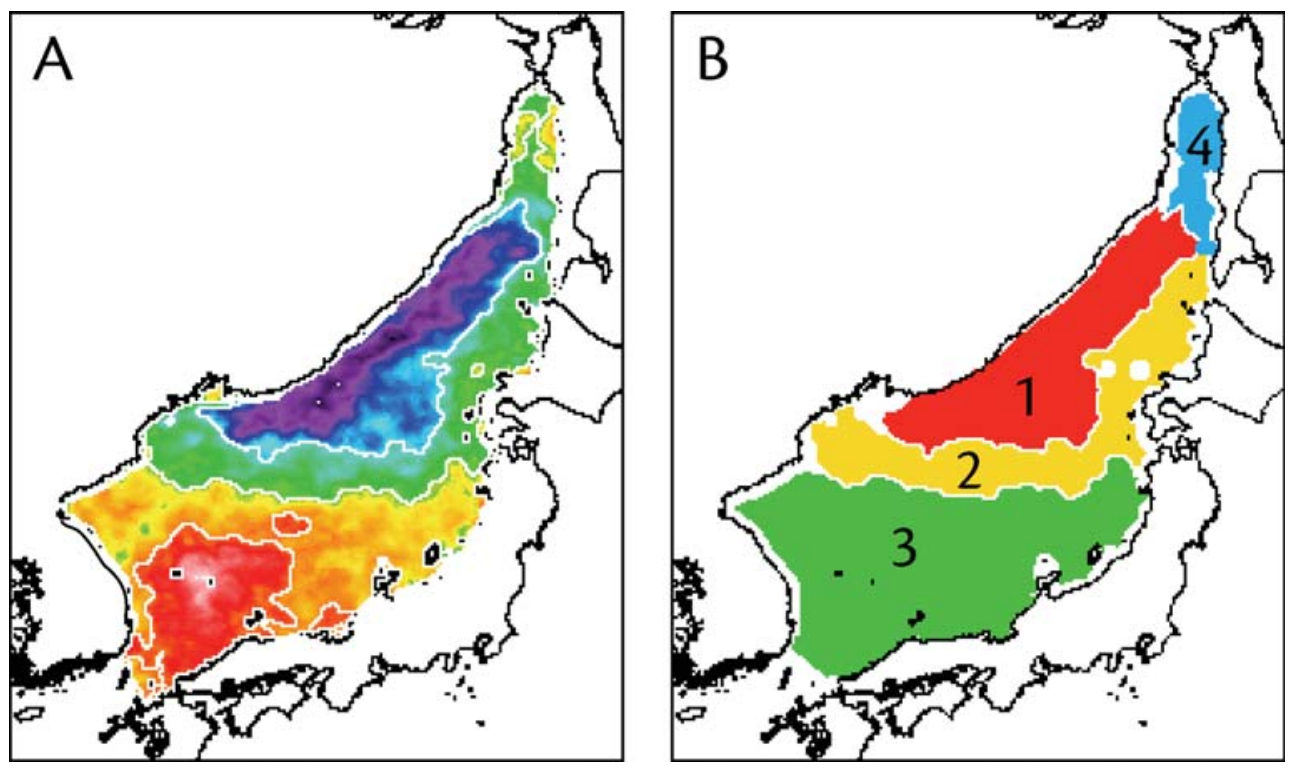

Figure 4. (A) First principal component of chlorophyll variability. (B) Four characteristic domains of the JES based on the Empirical Orthogonal Function analysis.

ern and southern regions and showed the frontal area in between (Figure 4). Based on this objective partitioning, four characteristic spatial domains were defined for which large-scale interannual variations in various biological parameters were explored.

Net primary production (NPP) by phytoplankton for each of the four spatial domains over the 10 years was estimated with an empirical model (Behrenfeld and Falkowski, 1997) using corresponding monthly satellitederived chlorophyll, photosynthetically available radiation (PAR), and SST. The methods of chlorophyll and NPP timeseries analysis within discrete geographic domains were described in Kahru and Mitchell (2000, 2002).

Time series of NPP (Figure 5) show distinct maxima during the spring bloom in April-May in all four domains. The fall bloom is smaller in magnitude but is also a recurrent feature in both the transition (2) and the southern (3) domains. In the far north domain (4), the spring bloom lasts longer and may merge with the fall bloom. Note also that in 2003 the fall bloom in this region was of greater magnitude (i.e., NPP) than the spring bloom. Primary production in northern regions $(1,4)$ usually exceeded that observed in the southern region (3). Seasonality in NPP in the southern region also was less than in other regions, with sustained levels of moderate NPP throughout the year. Interannual variability in the magnitude of the blooms was observed, however, a marked feature for all four areas was the especially low primary production during the El Niño year of 1997.
Previous studies (Yamada et al., 2005; Yamada and Ishizaka, 2006) have shown that the timing of the spring bloom depends on the strength of wind mixing and the vertical stratification. With relatively weak winds and a shallow upper mixed layer, the spring bloom starts and peaks early but the total primary production is relatively low. By contrast, in years with strong winter mixing and a deep thermocline, the spring bloom starts later but total primary production tends to be higher. Such mechanisms should drive the annual variations observed here.

\section{FLUORESCENCE SEASONALITY ACROSS THE SPF}

The role of the SPF in structuring the biogeography of the JES basin is clear in the broad-scale analyses of temperature, 

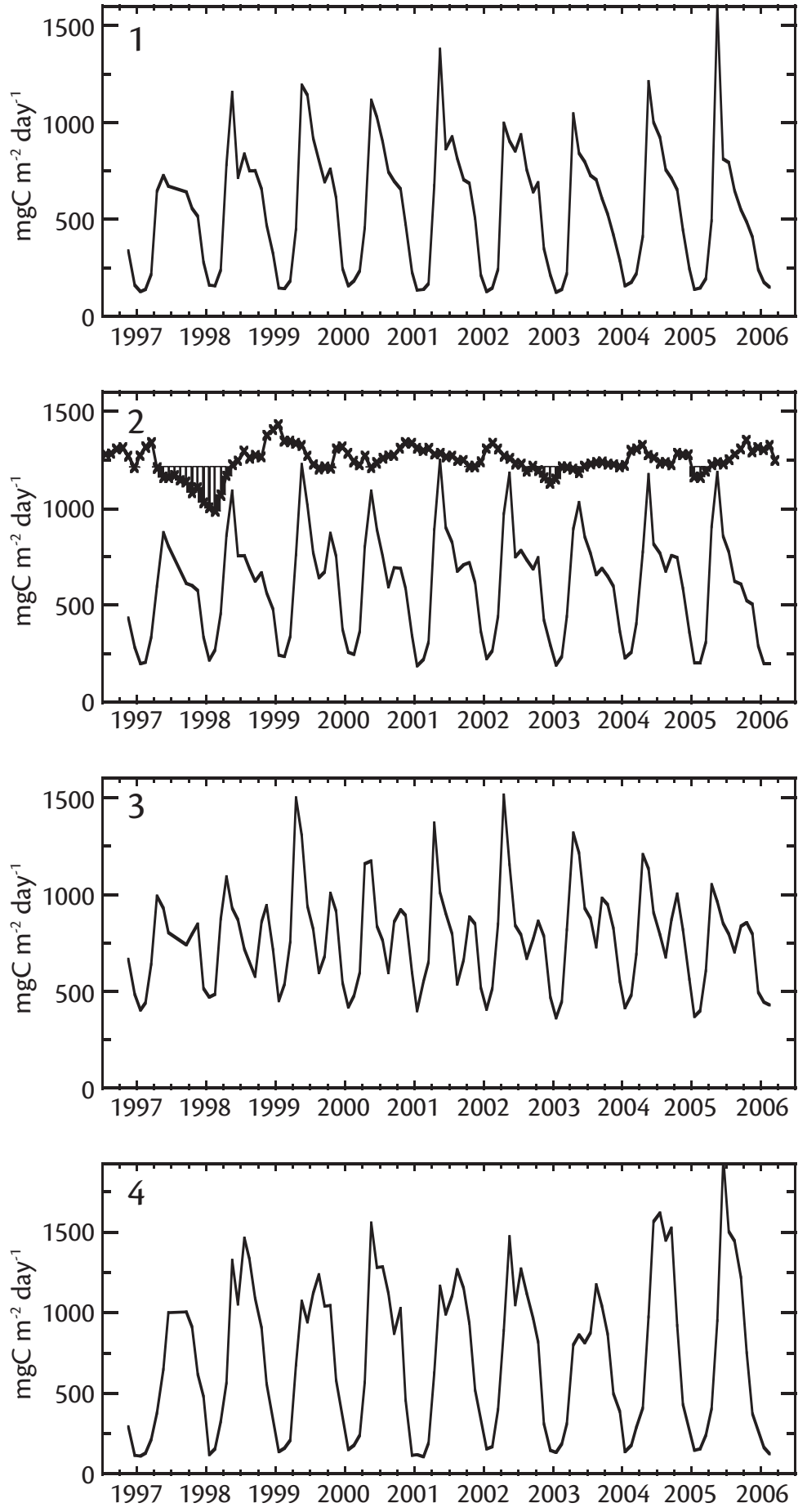

Figure 5. Time series of net primary production in the four domains defined in Figure 4. Panel 2 shows the Northern Oscillation Index, an El Niño index adapted for the North Pacific (Schwing et al., 2002). El Niño periods are shown as black-masked areas. The year label is centered at January 1. fluorescence, and primary production. These strong gradients are maintained on finer spatial scales at the SPF where the northern and southern water masses juxtapose. High-resolution sampling of the upper ocean was used to describe the anatomy of biological-physical associations at this dynamic boundary.

The cross-frontal structure of the SPF and its impact on the distribution and magnitude of chlorophyll fluorescence was described in early summer (May 1999) and winter (January 2000) using a SeaSoar towed vehicle. The SeaSoar was equipped with a conductivity-temperature-depth sensor (CTD), fluorometer, photosynthetically active radiation (PAR) sensor, multi-wavelength optical backscatter sensor, and multi-wavelength absorption/attenuation meter. Because the instrument sampled in the upper $250 \mathrm{~m}$ of the water column, subsurface detail was revealed that could not be resolved by satellitesensed ocean color.

The front was clearly evident in temperature, salinity, and density during both the spring and strongly windforced winter conditions (Figure 6). Phytoplankton biomass was enhanced at the front during both seasons. During the spring (May 1999) survey, the SPF was centered near $39.5^{\circ}-40^{\circ} \mathrm{N}$, as it had been in April 1999 (Figure 2), and was most clearly delineated by salinity. Chlorophyll concentration and suspended particulate material, indicated by optical backscatter $\left(b_{488}\right)$, were both elevated north of the front, at about 25-m depth, relative to south of the front where concentrations were reduced and chlorophyll and particles were deeper (40 m). We observed dramatic subduction along the 
May 22, 1999
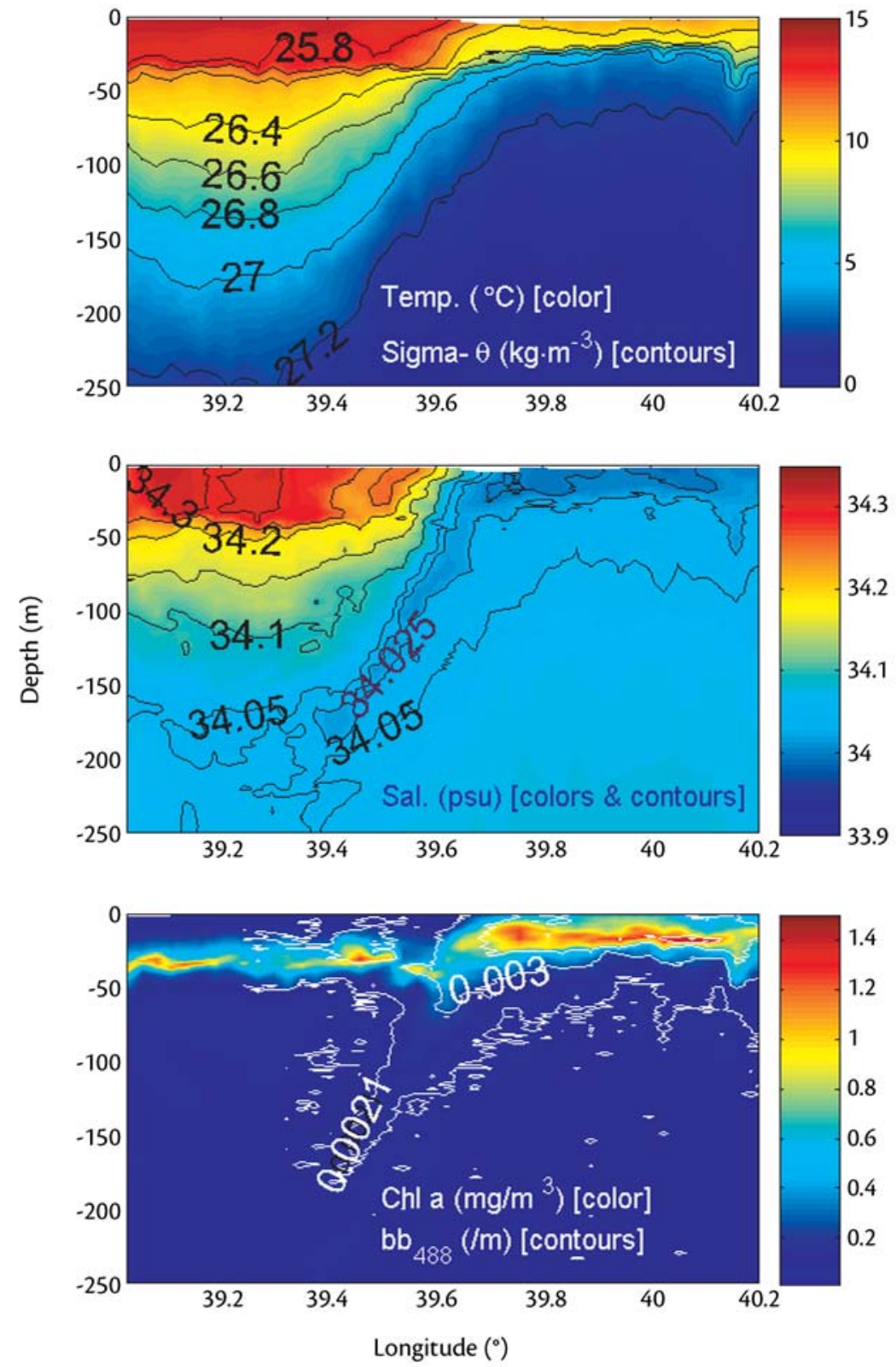

January 27,2000
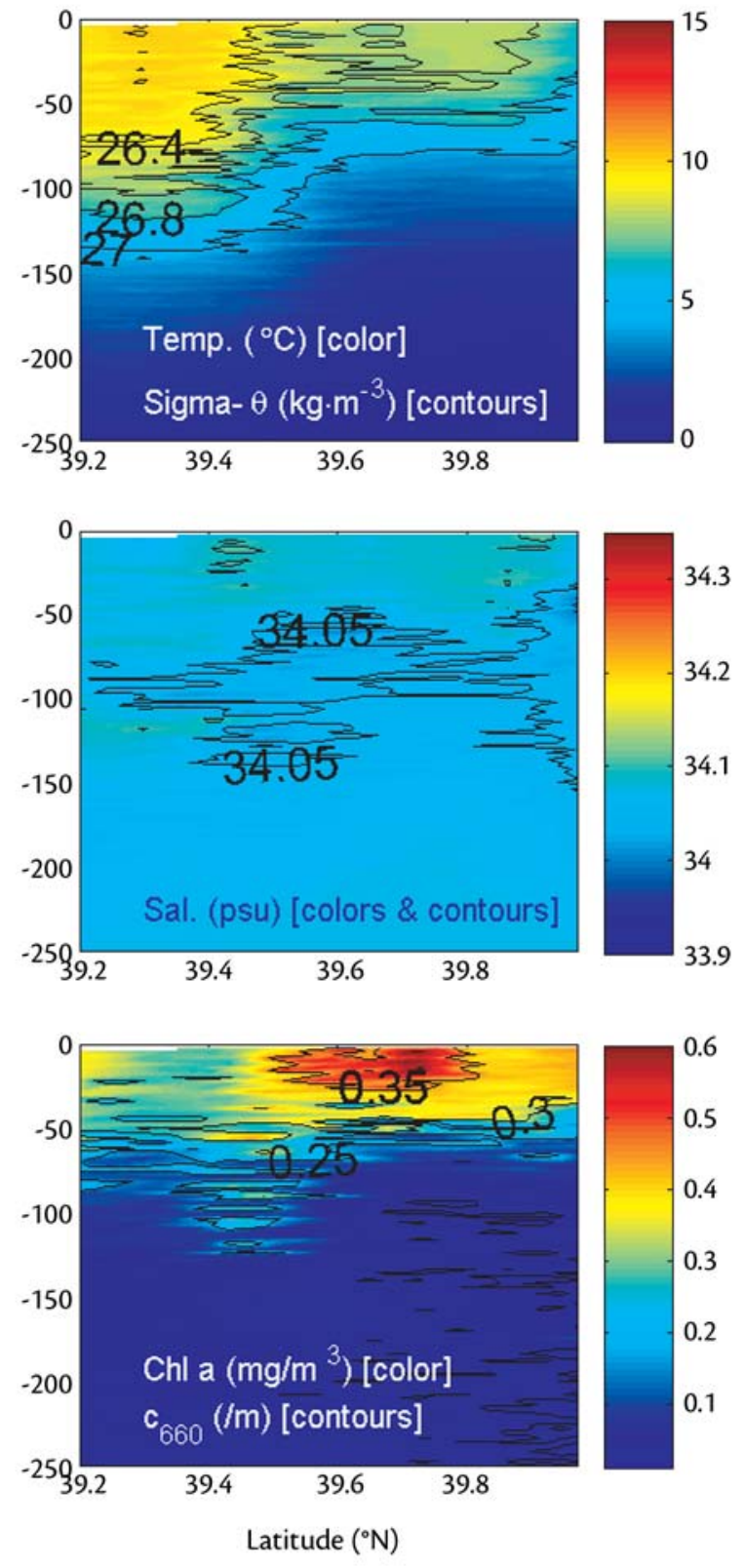

Figure 6. Cross-frontal SeaSoar sections for May 22, 1999 and January 27, 2000 of temperature, salinity, density (black contour lines over temperature), chlorophyll fluorescence, and backscatter at $488 \mathrm{~nm}$ (white contour lines over chlorophyll, May 1999) or beam attenuation coefficient at $660 \mathrm{~nm}$ (black contour lines over chlorophyll, January 2000). May 1999 section from along $134^{\circ} \mathrm{E}$ longitude and January 2000 section from along $134.233^{\circ} \mathrm{E}$ longitude. Subduction of water from the northern side of the front is clearly seen where chlorophyll extends downward from the surface. 
Figure 7. Distribution of large copepods, small copepods, and fluorescence along a transect crossing the SPF on July 4-7, 1999

(Figure 1). Temperature isotherms are overlain as cyan lines. Periods of day and night are indicated by black and white bars across the top of each panel. Large copepods were quantified using the low-magnification camera of the Video Plankton Recorder, while small copepods were quantified using the high-magnification camera.
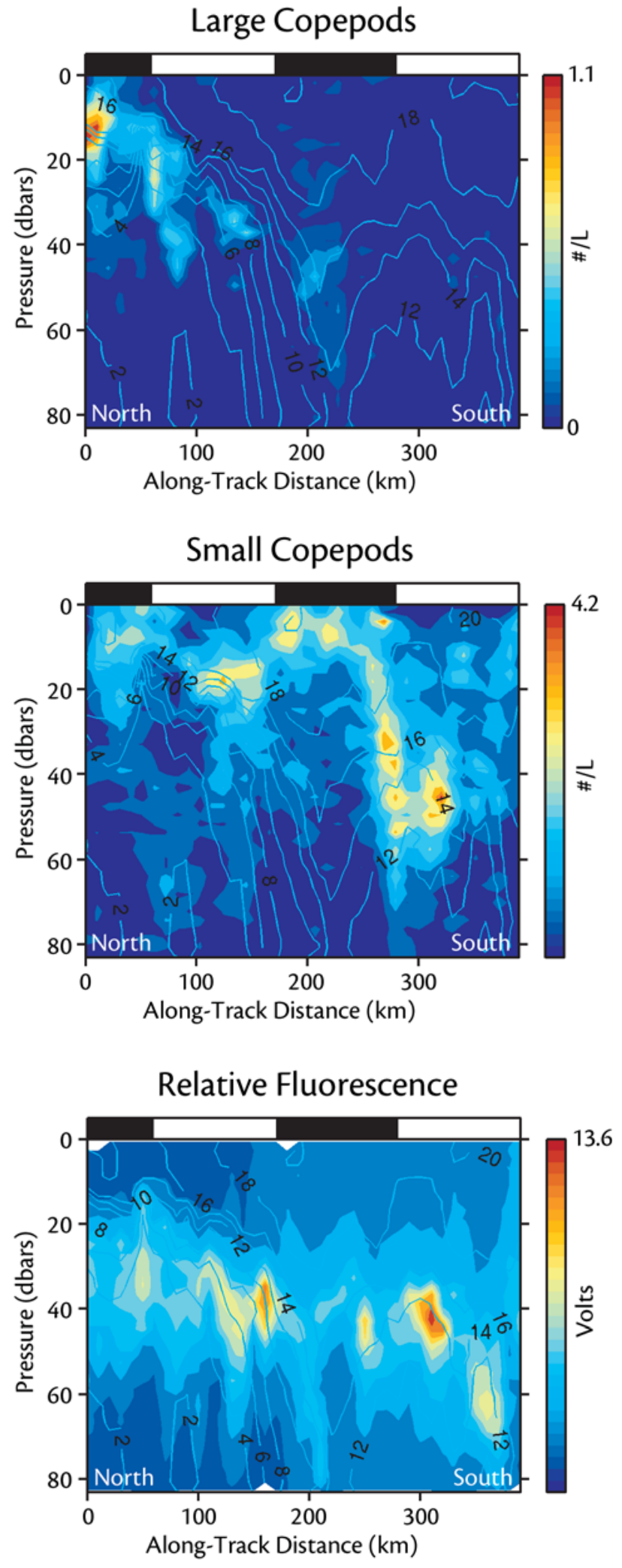

$27 \mathrm{~kg} \mathrm{~m}^{-3}$ isopycnal of water, chlorophyll biomass, and particles from north of the front to a depth of nearly $200 \mathrm{~m}$, below a layer of warmer, saltier water. The low salinity and elevated oxygen concentration (not shown) along the $27 \mathrm{~kg} \mathrm{~m}^{-3}$ isopycnal indicated that the source of the subducted water was cooler, fresher surface water from the north of the front. The deepening of this water may have occurred simply by overlaying it with warmer, saltier, less-dense Tsushima Current water advecting from the south or by active southward, downward transport. Regardless of the mechanism, the process resulted in transportation of primary production from the surface layer to nearly $200 \mathrm{~m}$, well below the euphotic zone.

During the winter (January 2000), increased chlorophyll again was observed at the SPF (Figure 6). This increased biomass, $0.75-1 \mathrm{mg} \mathrm{m}^{-3}$, was associated with enhanced stratification in the frontal region. As for May 1999, downward transport of chlorophyll along the frontal boundary occurred, although not as dramatically. Unlike May 1999 where the mechanism of downward transport was ambiguous, vertical circulation during the winter was driven by cold, downfront winds that resulted in subduction on the dense side of the front and upwelling on the frontal interface (Thomas and Lee, 2005). High-chlorophyll water was transported from the upper $50 \mathrm{~m}$ to a maximum depth of only $\sim 100 \mathrm{~m}$, in contrast to the subduction to $\sim 250 \mathrm{~m}$ observed during May. Although chlorophyll at the front was elevated $\left(0.75-1 \mathrm{mg} \mathrm{m}^{-3}\right)$, primary productivity was limited overall by lower light and increased vertical mixing. 


\section{ZOOPLANKTON}

\section{DISTRIBUTIONS AND THE SPF}

Different zooplankton communities also juxtapose at the dynamic SPF. Zooplankton species compositions of the northern and southern regions of the JES are distinct and associated with particular water-mass types (e.g., Meshcheryakova, 1960). The northern JES contains larger temperate and sub-polar colder water species, such as the large copepod species Neocalanus plumchrus (see references in Ashjian et al., 2005), while the southern JES contains smaller, more tropical species and genera such as the small copepod Oithona spp.

High-resolution sampling of zooplankton taxa distributions and abundance in association with hydrography in the southern JES, the SPF, and the northern JES just to the north of the SPF were conducted using a Video Plankton Recorder (VPR) during July 1999 (Ashjian et al., 2005, 2006) to describe how the SPF structures and separates these distinct communities (Figure 7). The VPR is essentially an underwater video microscope that images plankton and measures coincident environmental variables (e.g., temperature, salinity, fluorescence) at high temporal, and hence, spatial resolution (Davis et al., 1992a, b, 1996, 2004; Tang et al., 1998; Hu and Davis, 2005, 2006). For this study, the VPR was mounted on a V-fin that was towed behind the ship at 8-10 knots, surveying from the near-surface to $\sim 80 \mathrm{~m}$. In-focus plankton images were detected, measured, identified, and counted automatically; these counts then were divided by the calibrated image volume and merged with environmental variables by time to yield concentrations of plank- ton $\left(\# \mathrm{~L}^{-1}\right)$ at specific depths. The JES study was one of the first VPR surveys to be at least in part analyzed in near-real time on board the ship. The VPR was equipped with both high-resolution and low-magnification cameras that imaged $3 \mathrm{ml}$ and $29.6 \mathrm{ml}$, respectively. Because of the different image volumes, each camera effectively imaged and quantified different sizes of plankton and yielded separate distributions of large and small copepods.

Clear segregation of habitat by large and small copepods was seen across a summertime transect that extended from just to the north of the SPF to near the coast of Japan in the southern JES (Figure 1). Large copepods were most abundant just to the north of the SPF located at $150-\mathrm{km}$ along-track distance (defined according to T-S characteristics [Ashjian et al., 2005, 2006] and seen here as the subducting thermocline), while small copepods were most abundant to the south of the front. In the vertical, large copepods were found below the upper water column thermocline in wa- the range of migration of the smaller copepods was defined by the depth of the thermocline so that a shallower day distribution $(20 \mathrm{~m})$ was observed to the north of the front $(\sim 100-120-\mathrm{km}$ distance) where the thermocline was shallower, and deeper day distribution $(50 \mathrm{~m})$ was observed to the south of the front (300-km distance). For large copepods, the diel signal was very subtle, manifested only as an increase in abundance above the thermocline during the night at $\sim 200-\mathrm{km}$ distance. Large copepods may have migrated to the near surface at night to the north of the SPF (0-50-km distance); however, differentiation of that behavior from the association of large copepods with the thermocline is difficult. Elevated relative fluorescence was observed in the thermocline, with a peak located at the SPF consistent with what was observed using the SeaSoar (Figure 6). Both large and small copepods were associated with the fluorescence peak during the day while the small copepods migrated to the nearsurface during the night, presumably to

\section{...statistical analyses...yielded insight into seasonal cycles, regional variability, biogeography, and the biological response to physical...forcing not achieved previously.}

ter of $<10^{\circ} \mathrm{C}$, while the smaller copepods were confined primarily to warmer water $\left(>12^{\circ} \mathrm{C}\right)$ above the thermocline. Both large and small copepods demonstrated some evidence of diel vertical migration; utilize an alternative food supply (e.g., microzooplankton, small particles).

Examination of net tows taken in the different water types across the transect showed that to the north of the 
front the large copepods were primarily Neocalanus tonsa/plumchrus while the small copepods were primarily Oithona spp. By contrast, to the south of the front the large copepods were primar- sampling methods used in the ONR JES Program were of sufficiently high horizontal and vertical spatial resolution and synopticity to permit not only the identification of biological-physical as-

\title{
...this suite of observations and this
}

\section{approach represent a substantial contribution}

\author{
towards understanding biological processes \\ in highly dynamic ocean regions.
}

ily C. pacificus while Oithona and other small unidentified calanoids dominated small copepods (Ashjian et al., 2005).

Hence, species composition for the large copepods also changed across the region and this may have accounted for the different diel vertical migration patterns observed to the north and to the south of the SPF for that size category.

\section{CONCLUSION}

The high-resolution, nearly synoptic description of biological distributions and processes, and their association with physical features, presented here is representative of the exciting present and future direction of oceanography. Although significant understanding of the broad-scale distributions of hydrography, chlorophyll, primary production, and plankton were achieved in earlier studies of the JES, these conclusions were based on climatology, on widely spaced and temporally disparate measurements, and on low-resolution or integrated vertical sampling. By contrast, the field sociations, but also a more mechanistic understanding of how physical (atmosphere/ocean) processes associated with the SPF drive biological distributions and processes. The statistical analyses of an extended, high-resolution time series of satellite temperature and chlorophyll data yielded insight into seasonal cycles, regional variability, biogeography, and the biological response to physical (ocean temperature, seasonality) forcing not achieved previously. Together this suite of observations and this approach represent a substantial contribution towards understanding biological processes in highly dynamic ocean regions. 四

\section{REFERENCES}

Arnone, R.A., and A.R. Parsons. 2004. Real-time use of ocean color remote sensing for coastal monitoring. Chapter 14 in Remote Sensing of the Coastal Environments, R.L. Miller, C.E. Del Castillo, and B.A. McKee, eds. Springer Publishing, Kluwer Academic, New York, NY. Ashjian, C.J., C.S. Davis, S.M. Gallager, and P. Alatalo. 2005. Characterization of the zooplankton community, size composition, and distribution in relation to hydrography in the Japan/East Sea. Deep-Sea Research II 52:1,363-1,392.

Ashjian, C.J., C.S. Davis, S.M. Gallager, and P. Alatalo. 2006. Erratum to: "Characterization of the zooplankton size composition and distribution in relation to hydrography of the Japan/East Sea" [Deep-Sea Research II 52(2005):1,363-1,392]. Deep-Sea Research II 53:442-449.

Behrenfeld, M.J., and P.G. Falkowski. 1997. Photosynthetic rates derived from satellite-based chlorophyll concentration. Limnology and Oceanography 42:1-20.

Davis, C.S., S.M. Gallager, and A.R. Solow. 1992a. Microaggregations of oceanic plankton observed by towed video microscopy. Science 257:230-232.

Davis, C.S., S.M. Gallager, M.S. Berman, L.R. Haury, and J.R. Strickler. 1992b. The Video Plankton Recorder (VPR): Design and initial results. Archiv für Hydrobiologie Beiheft, Ergebnisse der Limnologie 36:67-81.

Davis, C.S., S.M. Gallager, M. Marra, and W.K. Stewart. 1996. Rapid visualization of plankton abundance and taxonomic composition using the Video Plankton Recorder. Deep-Sea Research II 43:1,947-1,970.

Davis, C.S., Q. Hu, S.M. Gallager, X. Tang, and C.J. Ashjian. 2004. Real-time observation of taxa-specific plankton distributions: an optical sampling method. Marine Ecology Progress Series 284:66-75.

Dorman, C.E., R.C. Beardsley, N.A. Dashko, C.A. Friehe, D. Khelif, K. Cho, R. Limeburner, and S.M. Varlamov. 2004. Winter marine atmospheric conditions over the Japan Sea. Journal of Geophysical Research 109:C12011, doi:10.1029/2001JC001197.

Gould, R.W., Jr., and R.A. Arnone. 2004. Temporal and spatial variability of satellite sea surface temperature and ocean color in the Japan/East Sea. International Journal of Remote Sensing 25(7-8):1,377-1,382.

Hase, H., J.-H. Yoon, and W. Koterayama. 1999. The current structure of the Tsushima Warm Current along the Japanese Coast. Journal of Oceanography 55:217-253.

Hirakawa, K., M. Kawano, S. Nishihama, and S. Ueno. 1995. Seasonal variability in abundance and composition of zooplankton in the vicinity of the Tsushima Straits, Southwestern Japan Sea. Bulletin of the Japan Sea National Fisheries Research Institute 
45:25-38.

$\mathrm{Hu}$, Q., and C. Davis. 2005. Automatic plankton recognition with co-occurrence matricies and Support Vector Machine. Marine Ecology Progress Series 295:21-31.

$\mathrm{Hu}$, Q., and C. Davis. 2006. Accurate automatic quantification of taxa-specific plankton abundance using dual classification with correction. Marine Ecology Progress Series 306:51-61.

Isoda, Y. 1994. Interannual SST Variations to the North and South of the Polar Front in the Japan Sea. La Mer 32:285-294.

Isoda, Y., S. Saitoh, and M. Mihara. 1991. SST Structure of the Polar Front in the Japan Sea. Pp. 103-112 in Oceanography of Asian Marginal Seas, K. Takano, ed. Elsevier, Burlington, MA.

Kahru, M., and B.G. Mitchell. 2000. Influence of the 1997-98 El Niño on the surface chlorophyll in the California Current. Geophysical Research Letters 27:2,937-2,940.

Kahru, M., and B.G. Mitchell. 2002. Influence of the El Niño-La Niña cycle on satellitederived primary production in the California Current. Geophysical Research Letters 29:1,846.

Khelif, D., C.A. Friehe, H, Jonsson, Q. Wang, and K. Rados. 2005. Wintertime boundarylayer structure and air-sea interaction over the Japan/East Sea. Deep-Sea Research II 52:1,525-1,546.

Kim, K., K.-R. Kim, J.-Y. Chung, H.-S. Yoo, and S.-G. Park. 1991. Characteristics of physical properties in the Ulleung Basin. Journal of the Oceanology Society of Korea 26:83-100.

Kim, K., K.-R. Kim, Y.-G. Kim, Y.-K. Cho, J.-Y. Chung, B.-H. Choi, S.-K. Byun, G.-H. Hong, M. Takematsu, J.-H. Yoon, Y. Volkov, and M. Danchenkov. 1996. New findings from CREAMS observations: Water masses and eddies in the East Sea. Journal of the Korean Society of Oceanography 31:155-163.

Lee, D.-K., and P.P. Niiler. 2005. The energetic surface circulation patterns of the Japan/East Sea. Deep-Sea Research II 52:1,547-1,563.

Meshcheryakova, I.M. 1960. Seasonal changes of the plankton in offshore waters of the Japan Sea. Izvestia TINRO 46:95-144 (in Russian).

Miller, C.B., and M. Terazaki. 1989. The life histories of Neocalanus flemingeri and Neocalanus plumchrus in the Sea of Japan. Bulletin of the Plankton Society of Japan 36:27-41.
Mitchell, D.A., D.R. Watts, M. Wimbush, W.J. Teague, K.L. Tracey, J.W. Book, K.-I. Chang, M.-S. Suk, and J.-H.Yoon. 2005. Upper circulation patterns in the Ulleung Basin. DeepSea Research II 52:1,617-1,638.

Morioka, Y., M. Nagahara, and Y. Komaki. 1977. Calanoid copepods as indicators of the cold watermass in the Japan Sea. Bulletin of the Japan Sea Regional Fisheries Research Laboratory 28:51-58.

Nishimura, S. 1969. The zoogeographical aspects of the Japan Sea. Publications of the Seto Marine Biological Laboratory 27.

Park, J.-S., S.-S. Lee, Y.-S. Kang, and S.-H. Huh. 1991. Distribution of indicator species of copepods and chaetognaths in the middle East Sea of Korea and their relationships to the characteristics of water masses. Bulletin of the Korean Fisheries Society 24:203-212.

Preller, R.H., and P.J. Hogan. 1998. Oceanography of the Okhotsk and the Japan/East Sea. Pp. 49-481 in The Sea, vol. 11, R. Robinson, and K. Brink, eds. John Wiley and Sons, Inc., New York, NY.

Riser, S.C., and G. Jacobs. 2005. The Japan/East Sea: A historical and scientific introduction. Deep-Sea Research II 52:1,359-1,362.

Schwing, F.B., T. Murphree, and P.M. Green. 2002. The Northern Oscillation Index (NOI): A new climate index for the northeast Pacific. Progress in Oceanography 53:115-139.

Shin, H.R., S.K. Byun, C. Kim, S. Hwang, and C.W. Shin. 1995. The characteristics of structure of warm eddy observed to the northwest of Ullungdo in 1992. Journal of the Korean Society of Oceanography 30:39-56.

Suh, Y.-S., B.G. Mitchell, and K.-S. Lim. 1999. A recurring eddy off the Korean northeast coast captured on satellite ocean color and sea surface temperature imagery. Journal of the Korean Society of Remote Sensing 15(2):175-181.

Talley, L.D., V. Lobanov, V. Ponomarev, A. Sualyuk, P. Tischenko, I. Zhabin, and S. Riser. 2003. Deep convection and brine rejection in the Japan Sea. Geophysical Research Letters 30(4):1159, doi:10.1029/2002GL016451.

Talley, L.D., P. Tischenko, V. Luchin, A. Nedashkovskiy, S. Sagalaev, D.-J. Kang, M. Warner, and D.-H. Min. 2004. Atlas of Japan (east) Sea hydrographic properties in summer 1999. Progress in Oceanography 61:277-348, doi:10.1016/j.pocean.2004.06.011.
Tang, X., W.K. Steward, L. Vincent, H. Huang, M. Marra, S.M. Gallager, and C.S. Davis. 1998. Automatic plankton image recognition. Artificial Intelligence Review 12:1-23.

Thomas, L.N., and C.M. Lee. 2005. Intensification of ocean fronts by down-front winds. Journal of Physical Oceanography 35:1,0861,102, doi:10.1175/JPO2737.1

Tomczak, M., and J.S. Godfrey. 1994. Regional Oceanography: An introduction. Pergamon Press, Oxford.

Yamada, K., and J. Ishizaka. 2006. Estimation of Interdecadal Change of Spring Bloom Timing, in the Case of the Japan Sea. Geophysical Research Letters 33:L02608, doi:10.1029/ 2005 GL024792.

Yamada, K., J. Ishizaka, and H. Nagata. 2005. Spatial and temporal variability of satellite estimated primary production in the Japan Sea from 1998 to 2002. Journal of Oceanography 61:857-869. 